
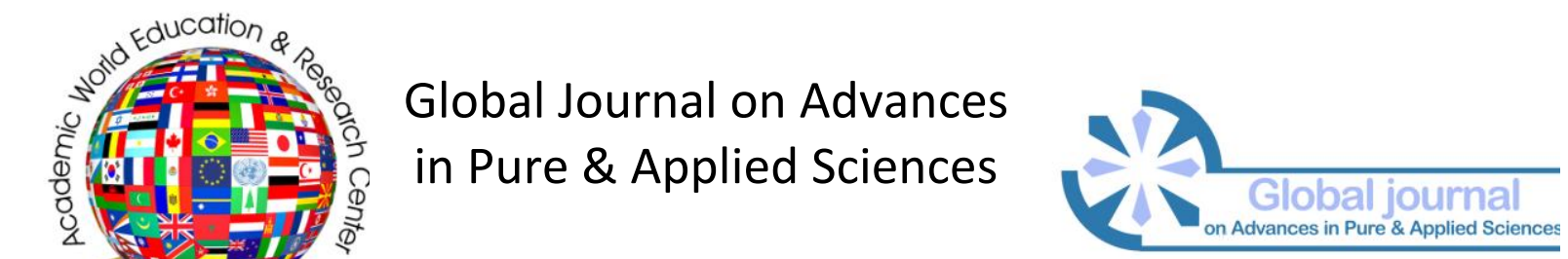

Issue 7 (2016) 170-174

Selected Paper of 2nd World Conference on Health Sciences ( $\mathrm{H}-\mathrm{SCl} 2015)$

30 April-02 May 2015 Efes Sürmeli Hotel \& Convention Center - İzmir, Kuşadası, Turkey

\title{
Innovation in Nursing Practices
}

Dilek Kara $^{\text {a }}$, Health School, Uludag University, Bursa, Turkey.

\section{Suggested Citation:}

Kara, D. (2016). Innovation in Nursing Practices, Global Journal on Advances in Pure \& Applied Sciences. [Online]. 07, pp 170-174. Available from: http://www.world-education-center.org/index.php/paas

Received November 08, 2014; revised Deceember 03, 2014; accepted March 10, 2015.

Selection and peer review under responsibility of Prof. Dr. Fahrettin Sadikoglu, Near East University. (C)2016 Academic World Education \& Research Center. All rights reserved.

\begin{abstract}
Nowadays the importance of scientific knowledge has been increasing and healt-care applications are changing rapidly. The increasingly aging population, chronic treatment of acute illness depending on which treatment applications have changed the perspective on the quality of the patient's care and maintenance. Innovation is the most important tool for improving the community's quality of life. Usually, the concept of innovation in the health sector and in particular for nursing, new approaches, technologies and ways of working is described as a process of development. Innovatio is vital for improving the quality of nursing care and it's sustainability. The planning of nursing practice, submission and evaluation of the use of innovative strategies are among the key factors that directly affect the quality of the service. Based on all of these reasons and in the light of the literature, this compilation is prepared to offer information of innovation in nursing practice.
\end{abstract}

Keywords: innovation, examples of innovation, nursing.

\footnotetext{
* ADDRESS FOR CORRESPONDENCE: Dilek Kara, Health School, Uludag University, Bursa, Turkey E-mail address: dilekkara15@hotmail.com / Tel.: +0-224-294-2454
} 
Kara, D. (2016). Innovation in Nursing Practices, Global Journal on Advances in Pure \& Applied Sciences. [Online]. 07, pp 170-174. Available from: www.propaas.eu

\section{Introduction}

Nowadays the importance of scientific knowledge has been increasing and healt-care applications are changing rapidly. The increasingly aging population, chronic treatment of acute illness depending on which treatment applications have changed the perspe80 012(v)-4at 
Kara, D. (2016). Innovation in Nursing Practices, Global Journal on Advances in Pure \& Applied Sciences. [Online]. 07, pp 170-174. Available from: www.propaas.eu

still possible $[11,12]$. Since nurses are at the center of care, there cannot be innovation in care system without nurses. There is almost no treatment or program in which nurses' initiative is not important. [14].

ICN reminds that in the health care system nurses "care" is an extremely important and in complex services what they do, what they do for, and being aware of that are the scientific basis, ICN also reminds them to make reviews the services they provide to question whether it is appropriate, in what way and they give the ways which is more effective, and perhaps reminds that quality research can provide cost effective care. In short; "If you fit Nursing into few business you have been doing, you do not even know the essence, if you cannot explain those businesses, there is no need to make a profession struggle, because you cannot success, you cannot be useful" Who will succeed it? ICN reminds and warns $[11,13]$.

\section{Examples of Innovation in the sphere of Nursing}

Examples of innovation performed by nurses in the world can be observed. Florence Nightingale is considered as the beginning of the modern nursing, in the 1800s, "more livable world; which will not be given to us, so without hesitation we should try to create this world. We must change the life rather than to comply, "she pointed to the necessity and inevitability of change. We see that Nightingale holds the first record in the nursing field and the first person who made statistics in the world, she is the creator of the intensive care unit, as evidenced by its contribution to environmental improvement, and she also prove the relationship between infetion and care [13].

Again, Florence Nightingale, she found out that following childbirth there is "puerpal fever" related to the environment which is one of the oldest examples of innovation. She has observed the mother death rates after childbirth due to the fever and she arised the question "Whether home environment is more deadly compared to hospital environment after childbirth?" Her study showed that the death rate was higher in the home environment and her innovative thinking that has resulted as the rescue of many women's lives [3].

Locke et al. in evaluating the impact of introducing administrative assistants to support the workload of ward managers, focuses on the issue of innovation and increasing effectiveness. Findings from this study make interesting reading and provide evidence of how workload redistribution can support increased quality of care by enabling ward managers to spend less time on administrative tasks thus having increased time to spend with patients and leading staff [14].

As it was stated in to report of ICN (2009) Kambarami (1999) the care of preterm thought to be a dangerous process when there is a misuse of the incubator and it is also expensive, as an innovative strategy he developed "kangaroo care" model. In this model, the baby is left on the mother's bare chest, it provides control of body temperature with skin contact, it is economical, safe and socially applicable, itcan be adopted easily. Thus, it is used in many neonatal intensive care units for years [3].

Another innovation, made by a nurse, who won the innovation prize in 2009 , who is working in a renal transplant unit, Jamie Rutherford, made a study about "transplantation of plasma exchange in patients undergoing filtration. Rutherford was concerned about the the pre-transplant patients' situations who were losing time for filtration and dialysis plasma exchange, he made an innovation which reduces the time spent processing combined with two hours of driving device connectivity [5].

In an example of the innovation carried out by nurses in Turkey, an "inventor" recognized by the nurses, Özlem Bekteş developed "Stomakit". Stomakit adapter is for cutting the skin protective stoma dressing apparatus. It is used in the care and maintenance of colostomy, ileostomy, urostomy. Since it is transparent, it allows seeing the content from across the stoma and controlled safely, easily and it is also time efficient. Also thanks to the leaking of stoma content below the adapter side cutter and protective properties and it provides a dry dressing area [6]. 
Furthermore, the Faculty of Acıbadem University of Health Sciences can be given as examples of innovation developed by Turkish nurses, 'Nursing Creativity' themed project, organized by the Department of Nursing; Nursen Ülke won the first prize in the contest with the project "Portlet". "Portlet" project made life easier for chemotherapy patients, it helps them to get rid of the device called "infusor", it helps patient by giving the drugs in special pockets, so patients are able to pursue their daily life. In the same competition, "clogging branule" project developed by nurse Nuğran Arslan was in the second place, and nurse Hürkan Cantutan and Sema Kınataş "Smart Pajamas" project has won the third place [7]. In fact, such competitions encouraging innovation for nurses and quality are the most important ways that help nurses to exhibit their projects in this field.

\section{Conclusion}

As a result, nursing profession, in order to exist in the changing and evolving world order should keep open all channels, all the assets, merge them and should strengthen the professional education and knowledge should improve the quality of the assets held open to all members of the profession [1].

Although there are examples of innovation in the nursing field can be seen above, innovative ideas and services performed by nurses is becoming increasingly common today, all around the world. Nursing profession is strengthened by a rapidly evolving world it has to be to shed light on innovation and professional training. Therefore, innovation is increasingly getting strong today in all areas of work, innovative ideas and work developed by nurses should be supported by private and public institutions and the necessary procedures should be the promotion for nurses in this area.

\section{References}

[1]Bektes, O. Yaratici ve Yenilikci Hemsirelik. Received July 21, 2013 from: http://www.acibademhemsirelik.com/e-dergi/yeni tasarim/detay.asp?id=37.

[2] Dil, S., Uzun, M., \& Aykanat, B. (2012). Hemşirelik eğitiminde inovasyon.International Journal of Human Sciences, 9, 1217-1228.

[3] Gibson, R., \& Kelly, B. (2010). Stoking Your Innovation Bonfire: A Road Map to a Sustainable Culture as Ingenuity and Purpose, 1th. New Jersey, Wiley \& Sons Inc, 188.

[4] Herdman, E. A. (2009). Hemşirelik ve yenilikçilik. Hemşirelikte Eğitim ve Araştırma Dergisi, 6(2), 2-4.

[5] Received August 05, 2008 from: http://www.stomakit.com

[6] Received August 05, 2008 from: http://www.acibademhemsirelik.com/e.../hemsirelikte-yaraticilikyarismasi.pdf

[7] Received May 10, 2008 from: http://www.wikipedia.org/wiki/Inovasyon

[8] International Council of Nurses (ICN). Delivering quality, serving communities: Nurses leading care innovations. 3, place Jean-Marteau, 1201 Geneva, Switzerland: ICN; 2009

[9] International Council of Nurses (ICN). Delivering quality, serving communities: Nurses leading care innovations. Received April 05, 2014 from: http://www.icn.ch/publications/2009-deliveringqualityserving-communities-nurses-leading-care-innovations

[10] Jurow, S. (2006). Set in your ways. Business Officer, 39(8), 18-22.

[11] Kasıkcı, M. (2013). Hemşirelik Uygulamalarında Yenilikler ve Gelişmeler. 14. Ulusal Hemşirelik Kongresi Bildiri Kitabı, 25-27 Ekim 2013, Mugla pp 47-49.

[12] Leininger, M. (1986). Transcultural Care Theory. In: Marriner A (ed.) Nursing the Orists and Their Work. 1th ed. US. The C.V. Mosby Company, 144-160.

[13] Mcsherry, M., \& Douglass, M. (2011). Innovation in Nursing Practice: A Means to Tackling the Global Challenges Facing Nurses, Midwives and Nurse Leaders and Managers in the Future. Journal of Nursing Management, 19(2), 165-169. 
[14] National Health Service (NHS). Institute for Innovation and Improvement; Innovation Making it Happen. Received January 16, 2011 from: http://www.institute.nhs.uk/innovation/innovation/introduction.html

[15] Oslo Kılavuzu (3. Baskı). Received from: www.tubitak.gov.tr/tubitak content files/BTYPD/.../Oslo 3 TR.pdf (in Turkish).

[16] Terzioglu, F. Hemsirelikte Yenilikler. Received May 10, 2015 from: http://www.tkitv.org/.../1Hemşirelikte\%20Yenilikler-Prof.Dr.Füsun\%20Terzioğlu.pdf 